\title{
Translation of Culture-specific Phrases in the Holy Quran
}

\author{
Mojtaba Moradi \\ IAU, Qeshm Branch, Iran \\ Hossain Mohammad Sadeghi \\ IAU, Bandar Abbas Branch, Iran
}

\begin{abstract}
Translating cultural elements can be a demanding task due to the fact that such elements have specific meanings in the culture and language in which they arise but not necessarily in others. Taking this fact into account, the present study investigated the strategies used in translation of culture-bound elements in three English translation of Holy Quran and the frequency of such strategies. In this study, the data gathered consist of the terms related to Islamic law in the original Arabic text of Holy Quran based on the classification made by Khoramshahi (1990) as well as their equivalents in three English versions by Shakir (1985), Yusuf Ali (1996), and Pickthall (1996). To gather the required data, chapter thirty of holy Quran randomly selected. Then, the culture-specific elements of this chapter of Holy Quran were detected and were compared with their English equivalents to identify the strategies used in translating them. Finally, the frequency of the employed strategies was studied in order to find which strategy has the highest potential for conveying the intended meaning.
\end{abstract}

Index Terms - religious translation, culture-specific items, holy Quran

\section{INTRODUCTION}

Religious texts and the Holy Quran in particular, have played a significant role in the life of man throughout history by aiming at guiding mankind into the right path. Now, the question that arises is that how such a global guidance should be carried out; In other words, how the universal message of the Quran should be conveyed to the receivers.

This study sets the scene by introducing the problem and subsequent research questions. It also discusses the purpose of the study and ends in the definitions provided for the key terms used in the present study. Translation as a phenomenon is such an incredibly broad idea that it can be understood in many different ways. Therefore, not surprisingly, many different definitions have been offered, each reflecting a particular underlying theoretical model. The American theorist Venuti (1995) for example, define translation as "a process by which the chain of signifiers that constitutes the source -language text is replaced by a chain of signifier in target language which the translator provides on the strength of an interpretation"(p.17). Venuti (1995) sees the aim of translation as:

To bring back a cultural other as the same, the recognizable, even the familiar; and this aim always risks a wholesale domestication of the foreign text, often in highly self conscious projects, where translation serves an appropriation of foreign cultures for domestic agendas, cultural , economic , and political.(p. 18)

Newmark (1998) introduce (Culture specific items) which the readership is unlikely to understand and the translation strategies for this kind of concept depend on the particular text-type, requirement of the readership and client and importance of the cultural word in the text.

In this study effort will be made to compare culture bound terms concerning cultural specific concepts in the holy Quran and three English translation of them to see what kind of procedures have been used by different translators and which procedure(s) is / are the most appropriate one(s). In doing so, the strategies used in dealing with culture-bound elements will be identified and finally, the frequency of the applied strategies will be studied in detail.

The significance of proper translation of cultural items is most apparent in the translation of religious texts where even the mistranslation of one cultural item could result in the complete distortion of the meaning. As such, the importance and need for present study which attempts to identify the most appropriate procedures for translation of culture-bound terms in sacred texts, and the holy Quran in particular, is self-evident. In this regard, the problems found in the translation of cultural specific items are studied in order to determine which translating strategies are used and how they reconstitute the cultural notion of the source text in the target text.

The culture-bound terms were classified based on the taxonomy presented by Khoramshahi (1990). The data were gathered from analyzing the English equivalent of the Holy Quran. The acquired data are analyzed on the basis of the following translation strategies based on the Ivir (1987) model which includes seven procedures as:

(1). Definition (2). Literal translation (3). Substitution (4). Lexical creation (5). Omission (6). Addition (7). Borrowing. 
So, the present study could gain significance as it draws attention to different strategies employed by the translators to render culture-specific items into their English equivalent. furthermore, this study aims at scrutinizing whether there exists any point of similarity and differences between these procedures and strategies used in the translation of cultural specific concepts (CSCS) of Holly Quran that are used by three different translators.

\section{Culture-Bound Terms}

Cultural-specific items refer to those which have no equivalents or different positions in target reader's cultural system, thus causing difficulties of translation of their functions and meanings in the source text into target text. According to Hatim and Mason (1990, pp. 223-4) "it is certainly true that in recent years the translator has increasingly come to be seen as a cultural mediator rather than a mere linguistic broker. It is also true that, in any form of translation, translators tend to apply a general strategy that will favor either an SL-oriented approach, or a TL-oriented approach."

Newmark (1988, p.78) maintains that translation problems caused by culture-specific words arise due to the fact that they are intrinsically and uniquely bound to the culture concerned and, therefore, are related to the "context of a cultural tradition". There are many ways to categorize culture-specific items, for instance Newmark (1988) points out five areas that cultural items may come from: (1) ecology (flora, fauna, winds, etc), (2) material culture (artifacts food clothes houses and towns, transport), (3) social culture (work and leisure), (4) organizations, customs, ideas (political, social, legal, religion or artistic), and (5) gestures and habits.

\section{METHODOLOGY}

\section{Theoretical Model for Analysis}

The theoretical framework of the present study will be the classification made by Ivir (1987). He has proposed seven procedures in the translation of cultural items, namely, definition, literal translation, addition, omission, lexical creation, substitution, and borrowing.

The data gathered consist of the terms related to Islamic law in the original Arabic text of Holy Quran based on the classification made by Khoramshahi (1990) as well as their equivalents in three English versions by Shakir (1985), Yusuf Ali (1996), and Pickthall (1996). Then, Ivir's (1987) suggested procedures for translating culture-bound terms were applied to the terms in question to see which procedures have been preferred by those translators.

The purpose of this study was to find the strategies employed in translation of culture-bound terms in the English translation of Holy Quran and to investigate the frequency of the used strategies to determine which one has the highest potential for conveying the intended meaning.

\section{Materials}

This study is mainly descriptive. In the present study terms related to Islamic law in the original Arabic text of Holy Quran have been compared with their equivalents in three English versions in order to find culture-bound terms and to investigate in details the translation strategies adopted by the translators in dealing with these terms.

The data will be gathered from analyzing the 36 suras of chapter thirty of Holy Quran.

The reason for choosing the Holy Quran as the base for this study was two fold. First, the original Arabic text of the Holy Quran is complete with terms specific to Muslim culture thus highly appropriate for the current research. Secondly, the significance of the proper translation of cultural items is most apparent in the translation of the religious texts where even the mistranslation of one cultural element could result in the complete distortion of meaning. Keeping this in view, chapter thirty of Quran were randomly chosen as samples, these thirty six Sourahs have a number of peculiarities as: they are not so long that may cause tedium on the part of the readers about the central topic of that sura and also due to the fact that these sourahs are so popular among the non-Arab speakers including Persian speakers and are widely used with all the Muslims in a way that the majority of them are reading them by heart due to their widely use and repetition.

\section{Procedure}

As it was amply discussed respecting particular elements of each kind of translation the culture -bound words of all the thirty six Sourahs of chapter thirty were listed in tables .then, efforts were made to locate such terms in the Holy Quran, i.e. to find the verses containing each term. Afterwards, the equivalents of Arabic terms were identified in the above mentioned three English versions of the holy book. Next, Ivir's (1987) suggested procedures for translating culture-bound terms were applied to the terms in question to see which procedures have been preferred by those translators. then, the frequency of occurrence of each procedure was counted in order to see which translation procedure(s) has/have been used more frequently. finally, the distribution of the three translators procedure for translating terms related to Islamic Ahkam in the Holy Quran was presented in the tabular form for subsequent analysis and discussion.

\section{Framework of the Study}

One of the most revealing translation crisis points is when some reference to the Source Culture is made, and there is no obvious official equivalent. Different theorists have suggested different procedures in the translation of cultural items. For example, Vladimir ivir (1987) has proposed seven procedures:

1. Literal Translation: is often regarded as the procedure for filling of the cultural and lexical gaps in translation (ivir, 1987, p.41). In this procedure, a SL word or phrase,, as a translation unit, is translated into a TL word or phrase, without breaking the TL syntactic rules. 
2. Addition: may turn out to be necessary procedure in the translation of the implicit elements of culture (ibid, p.46). In this procedure, an addition and note is added after the translation of the TL word or phrase.

3. Definition: is a procedure that relies on what members of the target culture know in an attempt to make them aware of what they don't know (ibid, p.40).in other words, defining means reducing the unknown to the known and the unshared to the shared.

4.omission: is necessitated not only by the nature of cultural element but by the nature of the communicative situation in which such an element appears(ibid, p. 46).in this procedure ,SL word or phrase, as a translation unit, is dropped in the TLT.

5. Substitution: a procedure that is available to the translator in cases in which the two cultures display a partial overlap rather than a clear-cut presence vs. absence of a particular element of culture (ibid, p. 43). In this procedure, a SL cultural item is substituted by a TL term.

6. Lexical creation: is a procedure which greatly taxes the translator's ingenuity on the one hand and the receiver's power of comprehension on the other hand, hence it is less frequently used. It takes a variety of forms from lexical invention and word formation to the semantic extension or specialization of words that are already present in the target language (ibid, p.45).

7. Borrowing: is a frequently used procedure and one that assured a very precise transmission of cultural information (ibid, p.39).in this procedure, the SL word is brought into the target language text.

\section{Analysis of Culture-Bound Elements of the holy Quran}

In the following parts the collected data will be analyzed after being classified on the basis of the before mentioned framework. It should be added that although the emphasis of this study is culture-bound elements, but in the following sections some of the culture-bound elements will be offered in tables, to help the reader have a clear understanding of culture-bound elements and their meaning in context. 
TABLE. 1

TERMS TRANSLATED USING THE PROCEDURE "LITERAL TRANSLATION"

\begin{tabular}{|c|c|c|c|}
\hline Terms & T1(Shakir) & T2(Yusuf Ali) & T3(Pickthall) \\
\hline ابن السبيل & Wayfarer & Wayfarer & Wayfarer \\
\hline اسفل سفلين & lowest of the low & (to be) the lowest of the low & the lowest of the low \\
\hline الازلام & (dividing by) arrows & (Divination by) arrows & Divining arrows \\
\hline الامر بالمعروف & Enjoin what is right & Enjoin what is right & Enjoin right conduct \\
\hline الكفرون & Unbelievers & ye that reject Faith & Disbelievers \\
\hline الايامى & Those who are single & Those who are single & Such of you as are solitary \\
\hline الاقسام & Swear & Swear & Swear \\
\hline الا يدى-قطعها & Cut of hands & Cut of hands & Cut of hands \\
\hline الايلاء & $\begin{array}{l}\text { Swear that they will not go in to their } \\
\text { wives }\end{array}$ & $\begin{array}{l}\text { Take an oath for abstention } \\
\text { from their wives }\end{array}$ & $\begin{array}{l}\text { Forswear their wives must } \\
\text { wait four months }\end{array}$ \\
\hline التين و الزيتون & I swear by the fig and the olive & By the Fig and the Olive & By the Fig and the Olive \\
\hline 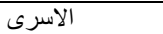 & Captives & Prisoners of war & Captives \\
\hline الاسبر & Captive & Captive & Prisoner \\
\hline الامه & Maid & Slave woman & Bondwoman \\
\hline الايمان & Oaths & Oaths & Oaths \\
\hline الحلف & Swear & Swear & Swear \\
\hline الحرام & Unlawful & Forbidden & Forbidden \\
\hline الحرمات & Sacred things & Things prohibited & Forbidden things \\
\hline الخمس & A fifth & A fifth share & A fifth \\
\hline 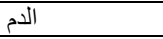 & blood & Blood & Blood \\
\hline 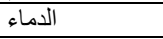 & Blood & Blood & Blood \\
\hline الدين الدين & Debt & Debts & Debt \\
\hline 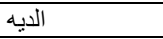 & Blood-money & Compensation & Blood-money \\
\hline 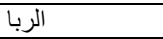 & Usury & Usury & Usury \\
\hline 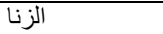 & Fornication & Adultery & Adultery \\
\hline 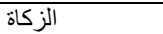 & Poor-rate & Regular charity & Poor-due \\
\hline الزوج & Husband & Husband & Husband \\
\hline الزوجين & Pairs & Pairs & Two spouses \\
\hline السفر & Journey & Journey & Journey \\
\hline السفها & The weak of understanding & The weak of understanding & Foolish \\
\hline الغسل & Wash yourselves & Wash whole body & Bath \\
\hline القربان & Offering & Sacrifice & Offering \\
\hline الكفار ات & Expiation & Expiation & Expiation \\
\hline المعاهدة & Covenant & Covenant & Covenant \\
\hline النحر & Sacrifice & Sacrifice & Sacrifice \\
\hline 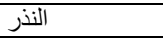 & Vow & Devotion & Vow \\
\hline النفقة & recompense & Recompense & Due payment \\
\hline النفى من البلاد & Be imprisoned & Exile from the land & Be expelled out of the land \\
\hline النهى عن المنكر & Forbid what is evil & Forbid evil & Forbid the wrong \\
\hline 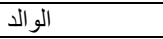 & Father & Father & Parent \\
\hline 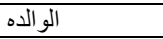 & Mothers & Mothers & Mothers \\
\hline الو الدان & Parents & Parents & Parents \\
\hline الوقف & Spend(benevolently) & Give(freely) & Spend \\
\hline الهبه & Grant & Grant & Vouchsafe \\
\hline الهايه & Present & Present & Present \\
\hline اليتامى & Orphans & Orphans & Orphans \\
\hline بيت الله الحرام & Sacred house & Sacred house & Sacred house \\
\hline خطبة النساء & Asking of (such) women in marriage & Make an offer of betrothal & Troth with women \\
\hline دين & Religion & Way & Religion \\
\hline سجيل & stones of baked clay & stones of baked clay & stones of baked clay \\
\hline طير ا ابابيل & birds in flocks & Flights of Birds & swarms of flying creatures \\
\hline ليلة القدر & the grand night & the Night of Power & the Night of Predestination \\
\hline
\end{tabular}

All translators have translated the above 52 terms literally. In the case of these terms, the following points are worth noting.

As regards the term سجيل term, none of the translators have used explanation about the kind of stone that god used for scratching the enemy.

Regarding the terms الخمس, none of the translators have used the English equivalent' tithe' meaning' a tenth of the goods some body produces or tenth part of one's income paid as a tax for the support of religious institutions' as such they have preferred the procedure of literal translation to that of substitution or cultural equivalent, since the root of the Arabic word is related to the Islamic law.

In the case of concepts such as اللينامين , etc all translators have used the same English equivalent since there is no cultural gap between such terms in the SL and TL and they are among the most-widely used lexical items in both the source and target language.

According to Ivir (1987) "the main value of this procedure is its faithfulness to the source language expression and its transparency in the target language"(p.41) 
TABLE. 2

TERMS TRANSLATED USING THE PROCEDURE OF "DEFINITION"

\begin{tabular}{|c|c|c|c|}
\hline Terms & T1(Shakir) & T2(Yusuf Ali) & T3(Pickthall) \\
\hline الحجاب & $\begin{array}{l}\text { Let down upon them their over- } \\
\text { garments }\end{array}$ & $\begin{array}{l}\text { Cast their outer garments over } \\
\text { their persons(when abroad) }\end{array}$ & $\begin{array}{l}\text { Draw their cloaks close round } \\
\text { them (when they go abroad) }\end{array}$ \\
\hline 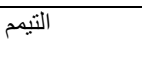 & Betake yourselves to pure earth & $\begin{array}{l}\text { Take for yourselves clean sand } \\
\text { or earth }\end{array}$ & Go to high clean soil \\
\hline 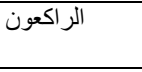 & $\begin{array}{l}\text { Those who bow down humbly(in } \\
\text { worship) }\end{array}$ & $\begin{array}{l}\text { Those who bow down } \\
\text { humbly(in worship) }\end{array}$ & Those who bow down(in prayer) \\
\hline 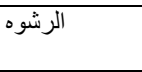 & To gain access thereby to the judges & Use it as bait for the judges & $\begin{array}{l}\text { Nor seek by it to gain the hearing } \\
\text { of the judges }\end{array}$ \\
\hline الساجدون & Who prostrate & $\begin{array}{l}\text { Who prostrate themselves in } \\
\text { prayer }\end{array}$ & Who fall prostrate (in worship) \\
\hline 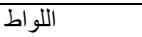 & Come to males in lust & Practice your lusts on men & Come with lusts unto men \\
\hline 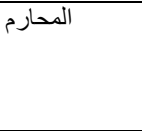 & $\begin{array}{l}\text { Fathers, brothers, brother's } \\
\text { sons ,sister's sons their own women, } \\
\text { of what their right hands possess }\end{array}$ & $\begin{array}{l}\text { Fathers or sons, brothers, } \\
\text { brother's sons, sister's sons, or } \\
\text { their women, or the (slaves) } \\
\text { whom their right hands possess }\end{array}$ & $\begin{array}{l}\text { Fathers, sons, brothers, brother's } \\
\text { sons, the sons of sisters or of their } \\
\text { own women, or slaves }\end{array}$ \\
\hline الوضوء & $\begin{array}{l}\text { Wash your faces and your hands as } \\
\text { far as the elbows, and wipe your } \\
\text { heads and your feet to the ankles }\end{array}$ & $\begin{array}{l}\text { Wash your faces, and your } \\
\text { hands(and arms) to the elbows; } \\
\text { rub your heads(with water);and } \\
\text { (wash) your feet to the ankles }\end{array}$ & $\begin{array}{l}\text { Wash your faces, and your hands } \\
\text { up to the elbows, and lightly rub } \\
\text { your heads and (wash) your feet } \\
\text { up to the ankles }\end{array}$ \\
\hline 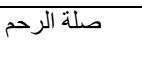 & What Allah has ordered to be joined & $\begin{array}{l}\text { What Allah has ordered to be } \\
\text { joined }\end{array}$ & $\begin{array}{l}\text { What Allah has ordered to be } \\
\text { joined }\end{array}$ \\
\hline ت ت تعدد الزوجات & $\begin{array}{l}\text { Marry such women as seem good to } \\
\text { you, two and three and four }\end{array}$ & $\begin{array}{l}\text { Marry women of your choice, } \\
\text { two or three or four }\end{array}$ & $\begin{array}{l}\text { Marry of the women, who seem } \\
\text { good to you, two or three or four }\end{array}$ \\
\hline ملك اليمين & What your right hand possesses & $\begin{array}{l}\text { Any thy right hand should } \\
\text { possess(as handmaidens) }\end{array}$ & $\begin{array}{l}\text { Those whom thy right hand } \\
\text { possesses }\end{array}$ \\
\hline
\end{tabular}

In the case of the above 11 terms, shown in table 4.2, all translators have adopted the procedure of definition.

As regards the terms all translators chose the definition procedure for better extension and focus on this matter, since they can substuted with words like bribery ,meaning' giving of money or favors to influence or corrupt another's conduct.

As regards the term التيمح , الوضوء all translators have used definition procedure, since by choosing literal translation procedure, a cultural gap can occur, and these terms is in the depth of Islamic and Muslim culture.

According to Ivir (1987) "definition can quiet accurately transmit the necessary cultural information depending how extensive it is made"(p.41)

TABLE. 3

TERMS TRANSLATED USING THE PROCEDURE OF "BORROWING"

\begin{tabular}{|l|l|l|l|}
\hline Terms & T1(Shakir) & T2(Yusuf Ali) & T3(Pickthall) \\
\hline البعل & Ba l & Baal & Baal \\
\hline الجنه & Jinns & Jinns & Jinns \\
\hline القبله & Qiblah & Qiblah & Qiblah \\
\hline القور سينين & mount Sinai & The Mount of Sinai & Mount Sinai \\
\hline
\end{tabular}

In the case of the above 4 terms, shown in table 4.3, all translators have adopted the procedure of borrowing. In this case the following point is worth noting.

The borrowing procedure is located in the third place about translation of cultural terms and in some situation is essential, as the term القبل , the best equivalent is "Qiblah", since this word have a long history and came back to the creation of Islam.

TABLE. 4

TRANSLATION PROCEDURE USED FOR THE TRANSLATION OF THE TERMEتاعتماع

\begin{tabular}{|l|l|l|l|}
\hline Term & T1 & T2 & T3 \\
\hline الاستمتاع & Profit by & Derive benefit from & Seek content(by marrying them) \\
\cline { 2 - 4 } & Literal translation & Literal translation & Literal translation, addition \\
\hline
\end{tabular}

Regarding the term الاستمناع, all translators have used literal translation but, T3 combined addition to the procedure.

TABLE. 5

TRANSLATION PROCEDURE USED FOR THE TRANSLATION OF THE TERM ابع لهب

\begin{tabular}{|l|l|l|l|}
\hline Term & T1 & T2 & T3 \\
\hline ابو له & Abu Lahab & the Father of Flame & Abu Lahab \\
\cline { 2 - 4 } & Borrowing & Literal translation & Borrowing \\
\hline
\end{tabular}

Regarding the table.5., T1\& T3 have adopted the procedure borrowing and T2 has applied literal translation. 
TABLE. 6

TRANSLATION PROCEDURE USED FOR THE TRANSLATION OF THE TERM التقتيل

\begin{tabular}{|l|l|l|l|}
\hline Term & T1 & T2 & T3 \\
\hline \multirow{2}{*}{ التقنيل } & (horrible)murdering & Slain (without mercy) & Slain with a (fierce)slaughter \\
\cline { 2 - 4 } & Literal translation, addition & Literal translation, addition & Literal translation, addition \\
\hline
\end{tabular}

According to table.6., all translators have adopted the same procedure for the translation of التقنيل.

TABLE.7

التهجد TRANSLATION PROCEDURE USED FOR THE TRANSLATION OF THE TERM

\begin{tabular}{|l|l|l|l|}
\hline Term & T1 & T2 & T3 \\
\hline \multirow{2}{*}{ التهدy } & Pray Tahajjud & Pray & Awake for \\
\cline { 2 - 4 } & Borrowing & Literal translation & Literal translation \\
\hline
\end{tabular}

Except for T1 the other two translators have translated the term التهجد literally.

TABLE. 8

الجزيه TRANSLATION PROCEDURE USED FOR THE TRANSLATION OF THE TERM

\begin{tabular}{|c|c|c|c|}
\hline Term & $\mathrm{T} 1$ & $\mathrm{~T} 2$ & T3 \\
\hline \multirow[t]{2}{*}{ الجزيه } & Tax & Jizya & Tribute \\
\hline & Literal translation & Borrowing & Literal translation \\
\hline
\end{tabular}

Regarding the term الجزيه T1 \&T3 have used literal translation and T2 has applied borrowing procedure.

TABLE.9

الجنب TRANSLATION PROCEDURE USED FOR THE TRANSLATION OF THE TERM

\begin{tabular}{|c|c|c|c|}
\hline Term & T1 & $\mathrm{T} 2$ & T3 \\
\hline \multirow[t]{2}{*}{ 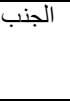 } & $\begin{array}{l}\text { Are under an obligation to perform } \\
\text { a bath }\end{array}$ & $\begin{array}{l}\text { In a state of ceremonial } \\
\text { impurity }\end{array}$ & Polluted \\
\hline & Literal translation & Literal translation, addition & Literal translation \\
\hline
\end{tabular}

As regards the term الجنب, T1\&T2 have used the procedure definition; T3 has translated it literally. In the Christian religious is baptize' meaning' perform ceremony of baptism by immersing in water (Christian ritual symbolizing admittance into the church) which is in some case near to the term الجنب which is special in Muslim.

TABLE. 10

TRANSLATION PROCEDURE USED FOR THE TRANSLATION OF THE TERMT الحج

\begin{tabular}{|l|l|l|l|}
\hline Term & T1 & T2 & T3 \\
\hline \multirow{2}{*}{ Term } & Pilgrimage & Hajj & Pilgrimage \\
\cline { 2 - 4 } & Literal translation & Borrowing & Literal translation \\
\hline
\end{tabular}

According to table.10, T1 \& T3 have used the procedure of literal translation; T2 has adopted the borrowing procedure.

TABLE. 11

الز انى TRANSLATION PROCEDURE USED FOR THE TRANSLATION OF THE TERM

\begin{tabular}{|l|l|l|l|}
\hline Term & T1 & T2 & T3 \\
\hline \multirow{2}{*}{ الزيy } & Fornicator & Man guilty of adultery or fornication & Adulterer \\
\cline { 2 - 4 } & Literal translation & Definition & Literal translation \\
\hline
\end{tabular}

Regarding the term الزانى, T1 \&T3 have used the literal translation procedure and T2 use definition.

TABLE.12

الزانيه TRANSLATION PROCEDURE USED FOR THE TRANSLATION OF THE TERM

\begin{tabular}{|c|c|c|c|}
\hline Term & $\mathrm{T} 1$ & T2 & $\mathrm{T} 3$ \\
\hline \multirow[t]{2}{*}{ 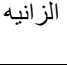 } & Fornicatress & Woman guilty of adultery or fornication & Adultress \\
\hline & Literal translation & definition & Literal translation \\
\hline
\end{tabular}

According to the table.30., all translators have applied literal translation except T2.

TABLE.13

TRANSLATION PROCEDURE USED FOR THE TRANSLATION OF THE TERM السارق TH

\begin{tabular}{|c|c|c|c|}
\hline Term & $\mathrm{T} 1$ & $\mathrm{~T} 2$ & T3 \\
\hline \multirow[t]{2}{*}{ السارق } & The man who steals & Male thief & Male thief \\
\hline & Definition & Literal translation & Literal translation \\
\hline
\end{tabular}

In the case of the term السارق, all translators but T1, who has used the procedure of definition, have translated it literally. 
TABLE. 14

السارقت| TRANSLATION PROCEDURE USED FOR THE TRANSLATION OF THE TERM

\begin{tabular}{|l|l|l|l|}
\hline Term & T1 & T2 & T3 \\
\hline \multirow{2}{*}{ السارقار } & Woman who steals & Female thief & Female thief \\
\cline { 2 - 4 } & Definition & Literal translation & Literal translation \\
\hline
\end{tabular}

Regarding the term السارقه, all translators but T1, who has used the procedure of definition, has translated it literally.

TABLE. 15

السائبت TRANSLATION PROCEDURE USED FOR THE TRANSLATION OF THE TERM

\begin{tabular}{|l|l|l|l|}
\hline Term & T1 & T2 & T3 \\
\hline \multirow{2}{*}{ السائ| } & Saibah & A she-camel let loose for free pasture & Saibah \\
\cline { 2 - 4 } & Borrowing & Definition & Borrowing \\
\hline
\end{tabular}

As regards the term, T1 \& T3 have used the procedure borrowing; T2 has adopted the procedure definition. This is another example of terms embedded highly in Arabic culture thus making it necessary to be translated by means of the procedures borrowing or definition.

TABLE. 16

السائل TRANSLATION PROCEDURE USED FOR THE TRANSLATION OF THE TERM

\begin{tabular}{|l|l|l|l|}
\hline Term & T1 & T2 & T3 \\
\hline \multirow{2}{*}{ الس } & him who asks & the petitioner (unheard) & the beggar \\
\cline { 2 - 4 } & Definition & Literal translation & Literal translation \\
\hline
\end{tabular}

As shown in table.16, T1 has used the procedure of definition and other two translators have used the term السائل literally.

TABLE. 17

الصلو ات TRANSLATION PROCEDURE USED FOR THE TRANSLATION OF THE TERM

\begin{tabular}{|l|l|l|l|}
\hline Term & T1 & T2 & T3 \\
\hline \multirow{3}{*}{ الصلو } & Prayers & (habit of)prayers & Prayers \\
\cline { 2 - 4 } & Literal translation & Literal translation, addition & Literal translation \\
\hline
\end{tabular}

In the case of the term الصلوات, except for T2, who have used the procedure of literal translation plus addition, other translators have preferred to literally.

TABLE. 18

TRANSLATION PROCEDURE USED FOR THE TRANSLATION OF THE TERM الظهار

\begin{tabular}{|c|c|c|c|}
\hline Term & T1 & $\mathrm{T} 2$ & T3 \\
\hline \multirow{3}{*}{ الظهار } & 11 & 12 & $1 J$ \\
\hline & $\begin{array}{l}\text { Wives whose backs you liken to the } \\
\text { backs of your mothers }\end{array}$ & Zihar & $\begin{array}{l}\text { Wives whom ye declare(to } \\
\text { be your mothers) }\end{array}$ \\
\hline & Definition & borrowing & definition \\
\hline
\end{tabular}

Regarding the term الظهار, T2 has used the procedure of borrowing; T1 \&T3 have adopted definition.

TABLE. 19

القار عه4TRANSLATION PROCEDURE USED FOR THE TRANSLATION OF THE TERM

\begin{tabular}{|c|c|c|c|}
\hline \multicolumn{4}{|c|}{ TRANSLATION PROCEDURE USED FOR THE TRANSLATION OF THE TERM القار عهIOA } \\
\hline Term & T1 & $\mathrm{T} 2$ & T3 \\
\hline \multirow[t]{2}{*}{ 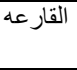 } & The terrible calamity & The (Day) of Noise and Clamour & The Calamity \\
\hline & Literal translation & Addition, literal translation & Literal translation \\
\hline
\end{tabular}

In the case of the term القارعه, all translators applied literal translation but, T2 use a combination of addition and literal procedure.

TABLE. 20

الكفال:TRANSLATION PROCEDURE USED FOR THE TRANSLATION OF THE TERM

\begin{tabular}{|c|c|c|c|}
\hline Term & $\mathrm{T} 1$ & $\mathrm{~T} 2$ & T3 \\
\hline \multirow[t]{2}{*}{ 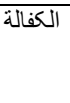 } & To have some body in charge & $\begin{array}{l}\text { To be charged with the } \\
\text { care of somebody }\end{array}$ & Be the guardian \\
\hline & Definition & definition & Literal translation \\
\hline
\end{tabular}

As regards the term الكفاله, T1 \& T2 have used definition procedure, and T3 literally translate it.

TABLE. 21

اللو اط TRANSLATION PROCEDURE USED FOR THE TRANSLATION OF THE TERM

\begin{tabular}{|c|c|c|c|}
\hline Term & $\mathrm{T} 1$ & $\mathrm{~T} 2$ & T3 \\
\hline \multirow[t]{2}{*}{ 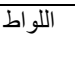 } & Come to males in lust & Practice your lusts on men & Come with lusts unto men \\
\hline & Literal translation & Borrowing & Literal translation \\
\hline
\end{tabular}


According to table.21., all translators use definition procedure, and focuses on men ,since this term is one of challengeable and meaningful culture bound term in Islam, all translators by defining stated that this action happen between two men instead of 'homosexual and lesbian' in western country. This is one of terms embedded highly in Arabic culture thus making it necessary to be translated by means of the definition procedure.

TABLE. 22

\begin{tabular}{|l|l|l|l|}
\multicolumn{5}{c}{ TRANSLATION PROCEDURE USED FOR THE TRANSLATION OF THE TERM المساجy } \\
\hline Term & T1 & T2 & T3 \\
\hline \multirow{2}{*}{ المساجد } & Masjids & Place for the worship of Allah & Sanctuaries \\
\cline { 2 - 4 } & Borrowing & definition & Literal translation \\
\hline
\end{tabular}

In the case of the term المساجد, T1 has used the procedure of borrowing; T2 has applied the procedure of definition and T3 has translated it literally.

TABLE. 23

المسكين TRANSLATION PROCEDURE USED FOR THE TRANSLATION OF THE TERM

\begin{tabular}{|l|l|l|l|}
\hline Term & T1 & T2 & T3 \\
\hline \multirow{2}{*}{ المسكين| } & Poor man & One that is indigent & A man in need \\
\cline { 2 - 4 } & Literal translation & definition & Literal translation \\
\hline
\end{tabular}

In the case of the term المسكين, T2 has used the procedure of definition; the other two translators have applied literal translation.

TABLE. 24

TRANSLATION PROCEDURE USED FOR THE TRANSLATION OF THE TERM المهاجرون T3

\begin{tabular}{|l|l|l|l|}
\multicolumn{5}{c}{ TRANSLATION PROCEDURE USED FOR THE TRANSLATION OF THE TERMigh } \\
\hline Term & T1 & T2 & T3 \\
\hline \multirow{2}{*}{ المهاجرونy } & Muhajirs & Those who forsook(their homes) & Muhajirin \\
\cline { 2 - 4 } & Borrowing & Definition & Borrowing \\
\hline
\end{tabular}

According to table 4.24., except for T2, other translators have used borrowing procedure for translating المهاجرون.

TABLE. 25

TRANSLATION PROCEDURE USED FOR THE TRANSLATION OF THE TERM النفت

\begin{tabular}{|l|l|l|l|}
\hline Term & T1 & T2 & T3 \\
\hline \multirow{2}{*}{ النفيy } & those who blow on knots & those who practise secret arts & malignant witchcraft \\
\cline { 2 - 4 } & Definition & Definition & Literal translation \\
\hline
\end{tabular}

All translators but T3 have translated the term النفتت in definition procedure.

TABLE. 26

\begin{tabular}{|c|c|c|c|}
\hline Term & $\mathrm{T} 1$ & $\mathrm{~T} 2$ & T3 \\
\hline \multirow[t]{2}{*}{ الوقف } & Spend(benevolently) & Give(freely) & Spend \\
\hline & Literal translation, addition & Literal translation, addition & Literal translation \\
\hline
\end{tabular}

Considering the terma الوقف, all translators except T3 have used the procedures of literal and addition.

TABLE. 27

TRANSLATION PROCEDURE USED FOR THE TRANSLATION OF THE TERM تو أبأ T3

\begin{tabular}{|c|c|c|c|}
\hline Term & $\mathrm{T} 1$ & T2 & T3 \\
\hline \multirow[t]{2}{*}{ تو ابأ } & oft-returning (to mercy). & Oft-Returning (in Grace and Mercy). & ready to show mercy \\
\hline & Literal translation, addition & Literal translation, addition & Literal translation \\
\hline
\end{tabular}

As regards the term توابا, all translators except T3 have used the procedures of literal and addition.

TABLE. 28

علق TRANSLATION PROCEDURE USED FOR THE TRANSLATION OF THE TERM

\begin{tabular}{|l|l|l|l|}
\hline Term & T1 & T2 & T3 \\
\hline \multirow{2}{*}{ علقy } & a clot & out of a (mere) clot of congealed blood & a clot \\
\cline { 2 - 4 } & Literal translation & Literal translation, addition & Literal translation \\
\hline
\end{tabular}

Considering the term علق, all translators have used literal translation; farther more, T2 has adopted the combination of procedures literal and addition.

TABLE.29

TRANSLATION PROCEDURE USED FOR THE TRANSLATION OF THE TERM حامبن

\begin{tabular}{|l|l|l|l|}
\multicolumn{4}{c}{ TRANSLATION PROCEDURE USED FOR THE TRANSLATION OF THE TERMdحام_ } \\
\hline Term & T1 & T2 & T3 \\
\hline \multirow{2}{*}{ حاميy|} & A burning fire & (It is) a Fire Blazing fiercely & (it is)Raging Fire \\
\cline { 2 - 4 } & Literal translation & Addition, definition & Literal translation,addition \\
\hline
\end{tabular}


In the case of the term حاميه, T1\& T3 have used literal translation and T2 has applied a combination of addition and definition procedure.

TABLE.30

Tرفات TRANSLATION PROCEDURE USED FOR THE TRANSLATION OF THE TERM

\begin{tabular}{|l|l|l|l|}
\hline Term & T1 & T2 & T3 \\
\hline \multirow{2}{*}{ ع ع ف } & Arafat & (mount)Arafat & Arafat \\
\cline { 2 - 4 } & Borrowing & Addition, borrowing & Borrowing \\
\hline
\end{tabular}

As regards the term عرفات, T2 has used a combination of the procedures of borrowing and addition; other translators have resorted to the procedure of borrowing. This term is one of the examples that rooted to the Muslim religious and have not a special place in the other religious cultures.

TABLE. 31

TRANSLATION PROCEDURE USED FOR THE TRANSLATION OF THE TERM العصر

\begin{tabular}{|l|l|l|l|}
\multicolumn{5}{|c}{ TRANSLATION PROCEDURE USED FOR THE TRANSLATION OF THE TERM } & T2 & T3 \\
\hline Term & T1 & B & \\
\hline \multirow{2}{*}{ العصدر } & I swear by the time & By (the Token of) Time (through the ages) & By the declining day \\
\cline { 2 - 4 } & Literal translation & Literal translation, addition & Literal translation \\
\hline
\end{tabular}

As regarding the term والعصر, all three translators have adopted literal translation, in addition to, T2 use addition procedure. This term is one of specific cultural words, that needed more explanation and noting, which none of the translators use it.

TABLE.32

همة لمز•TRANSLATION PROCEDURE USED FOR THE TRANSLATION OF THE TERM

\begin{tabular}{|c|c|c|c|}
\hline Term & $\mathrm{T} 1$ & $\mathrm{~T} 2$ & T3 \\
\hline \multirow[t]{2}{*}{ همزة لمزه } & slanderer, defamer & (kind of) scandal-monger and-backbiter & Slandering traducer \\
\hline & Literal translation & Addition, literal translation & Literal translation \\
\hline
\end{tabular}

According to the table 4.32., all translators applied literal translation but, T2 use a combination of addition and literal procedure.

\section{DATA ANALYSIS}

Since the strategies to transfer culture-bound terms mentioned ,first two tables are presented to show the number of different strategies of translation according to Ivir's model, then the frequency of the strategies used by translators for rendering culture-specific items will be shown in charts, and finally After the indication of the frequency of the strategies employed by translators, the percentage of the overall employed strategies based on this formula $\left(\mathrm{Pf}=\sum_{\mathrm{N}}^{F} \times\right.$ (100) are shown in three charts.

Analysis of Culture-Bound Elements

In the following parts the collected data will be analyzed after being classified on the basis of the before mentioned framework. It should be added that although the emphasis of this study is culture-bound elements, but in the following sections some of the culture-bound elements will be offered in their contexts, i.e. the entire verse or verses to help the reader have a clear understanding of culture-bound elements and their meaning in the origin context.

Analysis of "The holy Quran"

TABLE 1.

FREQUENCY OF THE OCCURRENCE OF EACH PROCEDURE

\begin{tabular}{|l|l|l|l|l|l|l|l|}
\hline $\begin{array}{c}\text { procedure } \\
\text { translator }\end{array}$ & $\begin{array}{l}\text { Literal } \\
\text { translation }\end{array}$ & definition & borrowing & Addition & omission & substation \\
\hline T1(shakir) & 72 & 17 & 10 & 1 & 0 & 0 & 0 \\
\hline T2(pickthal) & 61 & 19 & 9 & 11 & 0 & 0 & 0 \\
\hline T3(Yusuf Ali) & 77 & 13 & 8 & 2 & 0 & 0 & 0 \\
\hline Total sum & 210 & 49 & 27 & 14 & 0 & 0 & 0 \\
\hline percentage & $70 / 5 \%$ & $16 / 3 \%$ & $9 \%$ & $4 / 2 \%$ & 0 & 0 & 0 \\
\hline
\end{tabular}

As shown above, the procedures of literal translation, definition, borrowing and addition are the most -used procedures adopted by the above translators;

As the results showed literal translation procedure, is the most common strategy to render cultural elements. This is used 210 times between all translators.

Since most of the Arabic culture-bound elements do not exist in target culture, the translators preferred to replace them with some sort of paraphrase or literally translated terms, which does not necessarily involves a target culturebound term in order to transfer the intended meaning.

The next most common strategy is "definition" which is used 49 times between all translators, and the third common strategy which consists of 27 instances is borrowing strategy. And the last but not least, the procedure of addition 
located with 14 instances during this survey. Finally, according to the cumulative percentage: total sum of all this percentage is $100 \%$.

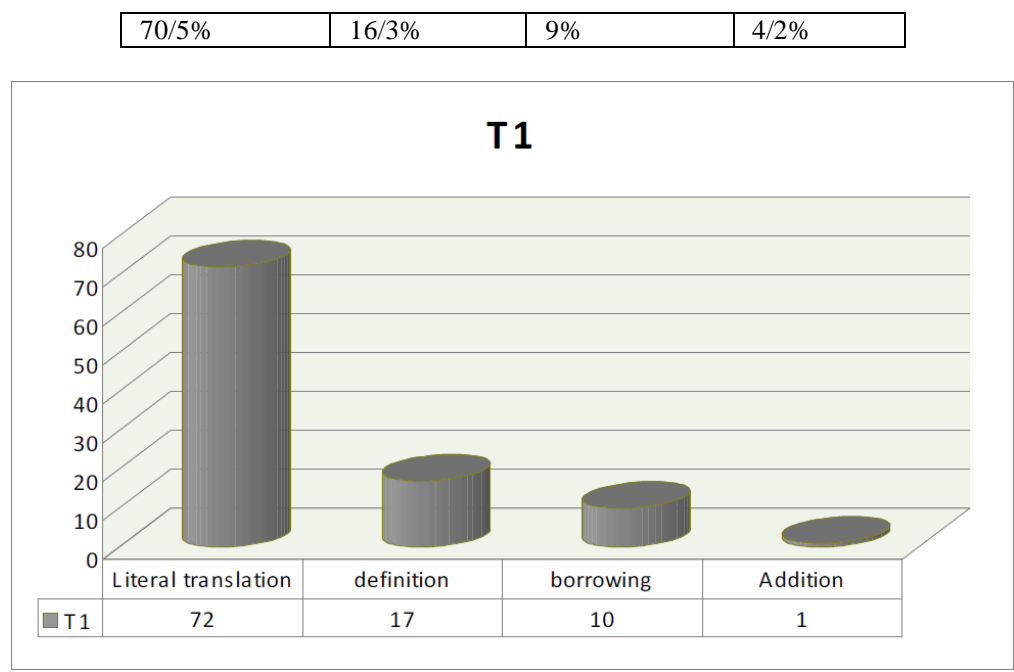

Chart 1. Frequency of the employed strategies in T1

This chart presented an analysis of the translation procedure adopted by Shakir. Literal translation is the preferred strategy. In compared with other translators, shakir is located in second places in applying literal translation.

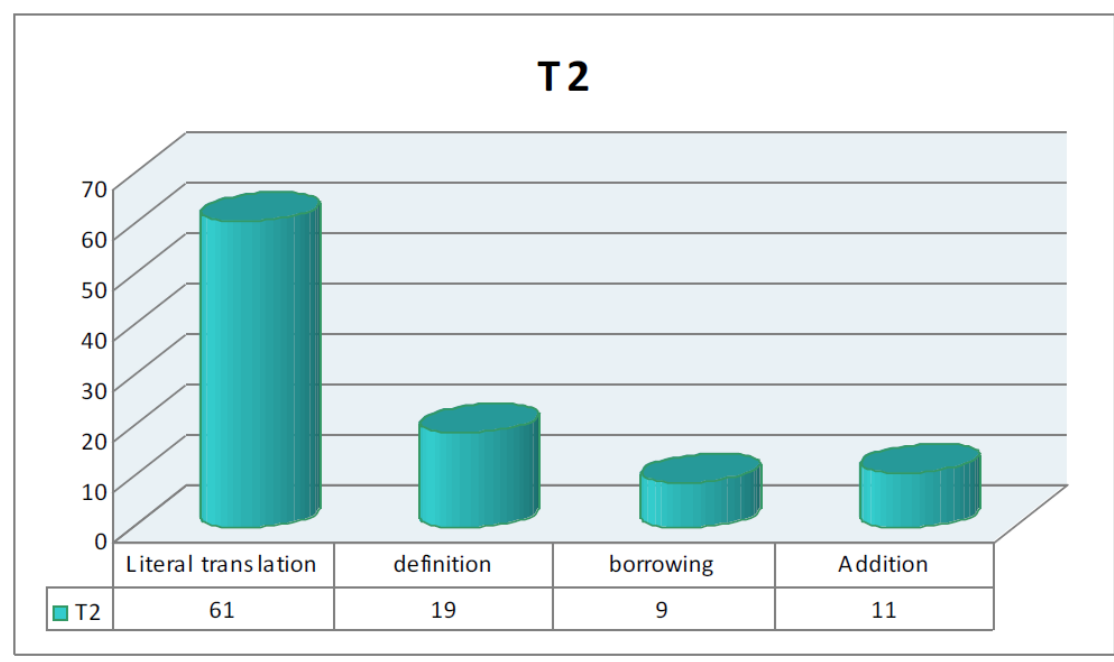

Chart 2. Frequency of the employed strategies in T2

This chart presented an analysis of the translation procedure adopted by Yusuf Ali. Literal translation is the preferred strategy. In compared with other translators, Yusuf Ali is located in third places in applying literal translation.

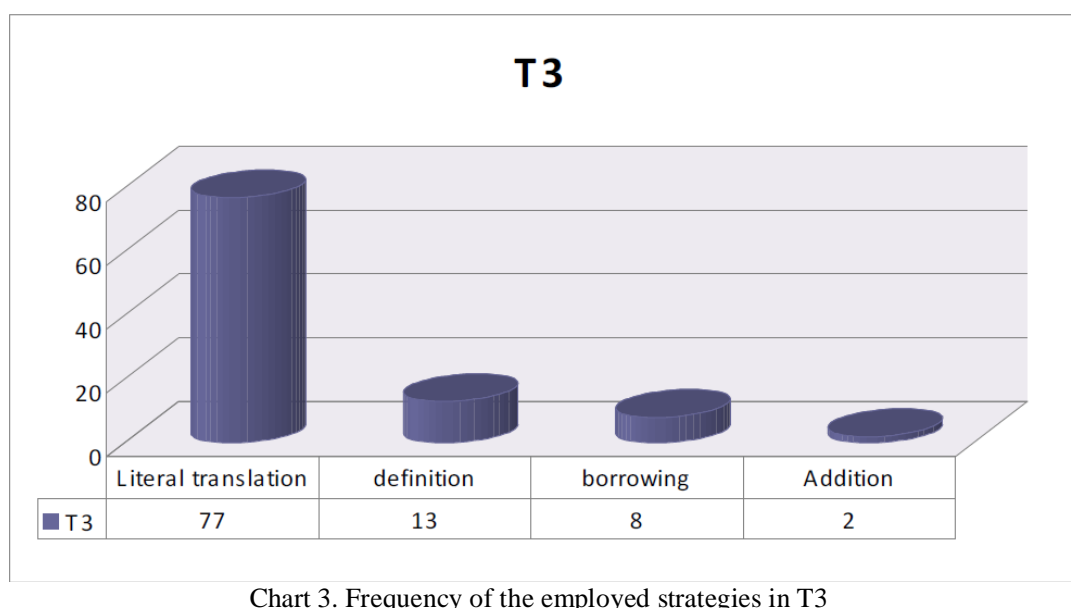

Chart 3. Frequency of the employed strategies in T3 
This chart presented an analysis of the translation procedure adopted by Pickthall. Literal translation is the preferred strategy. In compared with other translators, Pickthall is located in the first places in applying literal translation.

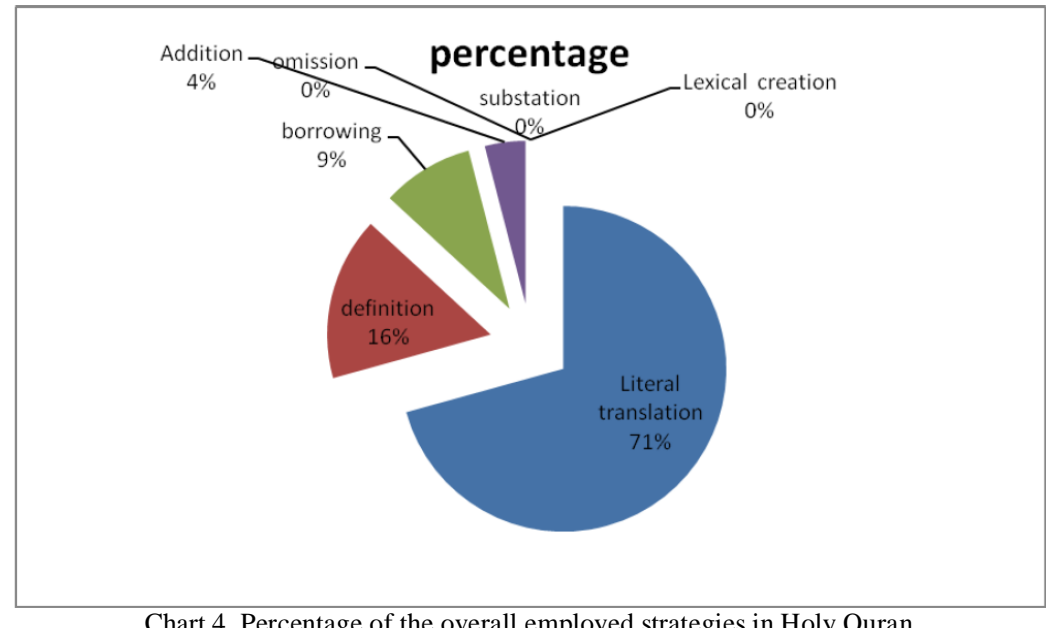

Chart 4. Percentage of the overall employed strategies in Holy Quran

Based on the researcher's analysis of the translation of the terms related to Ahkam in the Holy Quran, four out of seven of the above procedures were observed to be used by the chosen translators, which are evident in the above chart.

The other finding of study is some clearance of translators in selecting and equivalent finding as; in Yusuf Ali's translation, his choice of words - see tables in appendix - is peculiar of Quranic archaic lexicon and old-fashioned, in most of the cases give helpful explanation to the reader. Totally, he uses fully fledged criteria for transferring cultural element to the TT. On the other hand, Shakir and Picthal are much like each other in equivalent finding and especially in style and syntax. By attention to these examples it would be clear. Qur'an 4:158

(1)

YUSUF ALI: Nay, Allah raised him up unto Himself; and Allah is Exalted in Power, Wise;-

PICKTHAL: But Allah took him up unto Himself. Allah was ever Mighty, Wise.

SHAKIR: Nay! Allah took him up to Himself; and Allah is Mighty, Wise.

(2)

TABLE 2.

Similarities and Differences between Translators

\begin{tabular}{|l|l|l|l|}
\hline Term & Shakir & Yusuf ali & Pickthal \\
\hline الصلز & Prayers & (habit of)prayers & Prayers \\
\hline الزاتئ| & Fornicatress & Woman guilty of adultery or fornication & Adultress \\
\hline المساجد & Masjids & Place for the worship of Allah & Sanctuaries \\
\hline
\end{tabular}

By attention to the percentages of applying borrowing procedures among these three translators it can be obvious that Yusuf Ali applied more than the other translators in borrowing and less than using literal translation strategy.

As the results showed, in this study, the statistical presented in (table .1) revealed that the most frequently used procedure in the present study is literal translation. Therefore, it seems that the most appropriate procedure for translating culture- bound terms in the Holy Quran into English is the literal translation procedure opted most frequently by the selected professional translators.

As the final comment on the appropriateness of the procedures used for the translation of selected material, it is better to take a look on the statements made by Ivir (1987). He believes that no uniform treatments of unmatched elements of culture in translation is possible for all communicative situations, text-types, an individual text, or even a given cultural element repeated several times in the same text.

\section{CONCLUSION}

In the current research the focus has been on the translation of terms related to Islamic law (Ahkam) in the Arabic text of the Holy Quran into English and the translation procedures opted for by seven translators.

Analysis of the data presented in this study led to answering the two research questions presented in chapter one.

1. The analysis of the data shows that four out of seven strategies proposed by Ivir (1987) have been adopted by the selected translators in this study, namely, literal translation, definition, borrowing and addition. However, the remaining three procedures, i.e. omission, substation and lexical creation had no occurrence.

2. In this study, the statistical presented in table 4.31 revealed that the most frequently used procedure in the present study is literal translation. Therefore, it seems that the most appropriate procedure for translating culture- bound terms in the Holy Quran into English is the literal translation procedure opted most frequently by the selected professional translators. 
Therefore, it seems that the selected translators regard literal translation as the best choice for the translation of the selected cultural elements of the Holy Quran.

As the final comment on the appropriateness of the procedures used for the translation of selected material, it is better to take a look on the statements made by Ivir (1987). He believes that no uniform treatments of unmatched elements of culture in translation is possible for all communicative situations, text-types, an individual text, or even a given cultural element repeated several times in the same text. As he puts it,

For translator there is a hierarchy of opinions or an order of preference with respect to the translation procedures. He knows that borrowing, lexical creation, literal translation and definition (in that order) will explicitly draw the receiver's attention to the specific source-culture content, while substitution and omission will mask it; addition makes explicit the information that was unexpressed yet implicit in the source text...(p.47).

\section{REFERENCES}

[1] American psychological Association. (2002).Publication Manual of the American psychological Association (5 ${ }^{\text {th }}$ ed .). Washington, Dc.

[2] Hatim, B. and Mason, I. (1990). Discourse and the Translator. Longman: Longman Group Limited.

[3] Hatim, B., \& Munday, J. (2004).Translation .London and New York. Routledge.

[4] Ivir, V. (1987) procedures and strategies for the translation of culture. Routledge.

[5] Mollanazar, H. (2005). The Holy Quran: translation and ideological presuppositions. Translation studies Quarterly. (pp. 245252).

[6] Munday, J. (2001). Introducing Translation Studies, Theories and Applications. London and New York: Routledge

[7] Newmark, P. (1988, a).A textbook of translation. New York: prentice Hall.

[8] Newmark, P. (1988, a) .A textbook of translation. New York: prentice Hall.

[9] Nida, E. A., \& Taber, C. R. (1969). The theory and practice of translation. Leiden: E. J. Brill.

[10] Pickthall, M., (Tr). (1996). Meaning of the glorious Quran. New Delhi: Kitab Bhavan

[11] Shakir, M. H., Tr. (1985).the Holy Quran. New York: Tahrike Tarsile Quran.

[12] Toury, G. (1978). Translation across cultures. New Delhi: Bahari publications.

[13] Venuti, L. (1995). The Translator's Invisibility. New York and London: Routledge.

[14] Venuti, L. (1998). Strategies of translation. In M. Baker (Ed.), Encyclopedia of Translation Studies (pp. 240-244). London and New York: Routledge.

[15] Vermeer, H. (1987). What does it mean to translate? Indian journal of applied linguistics. (pp. 210-215).

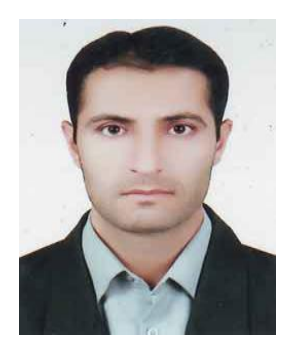

Mojtaba Moradi is a Ph.D student in TEFL from the IAU, Qeshm Branch, Iran.

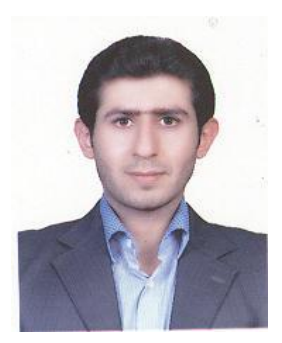

Hossain Mohammad Sadeghi has an M.A. in English Language Translation, from the IAU, Bandar Abbas Branch, Iran. 